\title{
High levels of solar radiation offset impacts of ocean acidification on calcifying and non-calcifying strains of Emiliania huxleyi
}

\author{
Peng Jin ${ }^{1}$, Jiancheng Ding ${ }^{1}$, Tao Xing ${ }^{1}$, Ulf Riebesell ${ }^{2}$, Kunshan Gao ${ }^{1, *}$ \\ ${ }^{1}$ State Key Laboratory of Marine Environmental Science/College of Ocean and Earth Sciences, \\ Xiamen University, Xiamen 361102, PR China \\ ${ }^{2}$ GEOMAR Helmholtz Centre for Ocean Research Kiel, Düsternbrooker Weg 20, 24105 Kiel, Germany
}

\begin{abstract}
Coccolithophores, a globally distributed group of marine phytoplankton, showed diverse responses to ocean acidification (OA) and to combinations of OA with other environmental factors. While their growth can be enhanced and calcification be hindered by OA under constant indoor light, fluctuation of solar radiation with ultraviolet irradiances might offset such effects. In this study, when a calcifying and a non-calcifying strain of Emiliania huxleyi were grown at $2 \mathrm{CO}_{2}$ concentrations (low $\mathrm{CO}_{2}$ [LC]: $395 \mu \mathrm{atm}$; high $\mathrm{CO}_{2}$ [HC]: $1000 \mu \mathrm{atm}$ ) under different levels of incident solar radiation in the presence of ultraviolet radiation (UVR), $\mathrm{HC}$ and increased levels of solar radiation acted synergistically to enhance the growth in the calcifying strain but not in the noncalcifying strain. HC enhanced the particulate organic carbon (POC) and nitrogen (PON) productions in both strains, and this effect was more obvious at high levels of solar radiation. While HC decreased calcification at low solar radiation levels, it did not cause a significant effect at high levels of solar radiation, implying that a sufficient supply of light energy can offset the impact of OA on the calcifying strain. Our data suggest that increased light exposure, which is predicted to happen with shoaling of the upper mixing layer due to progressive warming, could counteract the impact of OA on coccolithophores distributed within this layer.
\end{abstract}

KEY WORDS: Ocean acidification · Fluctuating light $\cdot$ UV radiation $\cdot$ Coccolithophore $\cdot$ Calcification

\section{INTRODUCTION}

Coccolithophores are a key group of marine primary producers, which play an important role in the ocean carbon cycle through photosynthesis as well as calcification (Hutchins 2011). They are also important in the sulphur cycle as one of the dominant producers of dimethylsulphide (DMS), which is known to play an import role in the climate system (Malin \& Erst 1997). However, such roles are thought to be affected by ocean acidification (OA) and associated chemical changes, including increases in $\mathrm{HCO}_{3}{ }^{-}$, $\mathrm{CO}_{2}$ and proton concentration $\left(\left[\mathrm{H}^{+}\right]\right)$, and decreases in $\mathrm{CO}_{3}{ }^{2-}$ and $\mathrm{pH}$ (Riebesell \& Tortell 2011). OA is

*Corresponding author: ksgao@xmu.edu.cn known to affect the cellular calcification rate of coccolithophores (Riebesell \& Tortell 2011) and influence their photosynthesis as well as elemental compositions (Riebesell et al. 2000, Gao et al. 2009, Müller et al. 2010, Jin et al. 2013).

In parallel with OA, daily levels of solar radiation exposure integrated within the upper mixed layer (UML) have been predicted to rise in future oceans with progressive global warming due to intensified ocean stratification and UML shoaling (Sarmiento et al. 2004). Studies of the interactive effect of OA with light on coccolithophores (Zondervan et al. 2002, Feng et al. 2008, Rokitta \& Rost 2012, Zhang et al. 2015) have shown that their responses to OA, in

() The authors 2017. Open Access under Creative Commons by Attribution Licence. Use, distribution and reproduction are unrestricted. Authors and original publication must be credited. 
terms of growth, photosynthesis and calcification, are strongly modulated by light. However, most of the previous studies applied constant light, which is very different from fluctuating solar radiation that phytoplankton cells are naturally exposed to. Fluctuating light treatments have been shown to substantially impact on elemental compositions, photosynthetic efficiencies and growth of phytoplankton, e.g. by van Leeuwe et al. (2005), Kropuenske et al. (2009), Shatwell et al. (2012), Jin et al. (2013), and Hoppe et al. (2015); however, the magnitude of the responses differed greatly among these studies. Such discrepancies could be attributed to different environmental conditions (e.g. temperature, $\mathrm{CO}_{2}$ levels, nutrient availability), which may alter the responses of phytoplankton to varying irradiance (Jin et al. 2013, Hoppe et al. 2015).

OA and fluctuating irradiance levels have the potential to synergistically affect phytoplankton, e.g. coccolithophores (Jin et al. 2013) and diatoms (Boelen et al. 2011, Hoppe et al. 2015), though we know little about their interactions to date. Fluctuating light reduced growth and strongly altered the effects of OA on photosynthesis of an Antarctic diatom, Chaetoceros debilis (Hoppe et al. 2015). Significant interactions between fluctuating light and OA were detected for pigment production rates and particulate organic carbon (POC) cell content, whicht were not affected by $\mathrm{OA}$ under constant light regimes (Hoppe et al. 2015). Similarly, a combination of OA and fluctuating light decreased carbon fixation, compared to fixation at an ambient $\mathrm{CO}_{2}$ level and under constant light, in the coccolithophore Gephyrocapsa oceanica (Jin et al. 2013). The growth of another species of coccolithophore, Emiliania huxleyi, was higher under indoor constant light, but became lower under outdoor fluctuating photosynthetic active radiation (PAR) (even with equivalent daily dose), and even further declined with addition of solar ultraviolet radiation (UVR, 280-400 nm) (Xing et al. 2015). Therefore, it is likely that changing levels of light and UVR interact with other abiotic factors to influence phytoplankton physiology.

Experiments in laboratory, using, for example, programmed lamps (Hoppe et al. 2015) or a solar simulator (Jin et al. 2013) to mimick natural mixing regimes, may not reflect natural solar irradiance, as they neglect the influence of solar UVR. UVR at 305 and $340 \mathrm{~nm}$ can penetrate (at $1 \%$ of surface intensity) as deep as 56 and $118 \mathrm{~m}$, respectively, in open oceans (Tedetti et al. 2007). Solar UVR therefore has the potential to impact on natural coccolithophores (e.g. E. huxleyi, that is found in the entire photic zone). For example, UVR decreases photosynthetic carbon fixation, calcification and growth of coccolithophores (Gao et al. 2009, Guan \& Gao 2010); however, these responses could be modulated by other environmental factors, such as OA (Sobrino et al. 2008, Gao et al. 2009, Li et al. 2012, Jin et al. 2013, Xu \& Gao 2015). OA increases the sensitivity of phytoplankton to UVR by increasing photoinhibition (Sobrino et al. 2008). In contrast, the studies of Li et al. (2012) and Jin et al. (2013) showed that OA could act antagonistically to reduce UV-induced photoinhibition of photosynthetic carbon fixation in a diatom and a coccolithophore (Li et al. 2012, Jin et al. 2013). Moderate levels of UVR may stimulate production of particulate inorganic carbon (PIC) in E. huxleyi (Xu \& Gao 2015). However, we still know little about the interactive effects of OA and solar radiation (including PAR and UVR with natural fluctuating regimes) on coccolithophores and the mechanisms involved.

The decreased calcification rate under OA is partially caused by increasing energy costs of calcification (Irie et al. 2010, Raven 2011, Raven \& Crawfurd 2012), which is required to sustain a sufficient supply of $\mathrm{CO}_{3}{ }^{2-}$ in the coccolith-forming vesicle, and net $\mathrm{H}^{+}$ efflux (Raven 2011). Therefore, based on the documented knowledge on the effects of OA and/or light intensity on E. huxleyi, we hypothesize that increased levels of supplied energy with high levels of solar radiation may offset the negative effects of OA on calcification of E. huxleyi. To test this hypothesis, we chose E. huxleyi PMLB 92/11, a calcifying strain, and E. huxleyi CCMP 2090, a non-calcifying strain, and grew them over a range of solar radiation intensities under natural solar radiation at ambient and elevated $\mathrm{CO}_{2}$ concentrations as projected for the end of this century (IPCC 2013), and then investigated the effects on growth, POC production and calcification.

\section{MATERIALS AND METHODS}

\section{Culture conditions}

Emiliania huxleyi strains PML B92/11 (calcifying) and CCMP 2090 (non-calcifying) were originally obtained from coastal waters off Bergen, Norway and from the South Pacific, respectively. Monospecific cultures of the 2 strains were grown semi-continuously by partially renewing the medium every $24 \mathrm{~h}$ with fresh medium pre-equilibrated at ambient (low $\mathrm{CO}_{2}$ [LC]: $395 \mu \mathrm{atm}$ ) or elevated (high $\mathrm{CO}_{2}$ [HC]:1000 $\mu$ atm) $p \mathrm{CO}_{2}$ levels. To maintain a stable carbonate system in the semi-continuous cultures, 
the cell density was maintained within a range of 1.5 to $3.0 \times 10^{4}$ cells $\mathrm{ml}^{-1}$ before and after diluting the cultures (Jin et al. 2013). The culture medium was prepared with artificial seawater enriched with Aquil medium (110 $\mu \mathrm{M}$ nitrate, $10 \mu \mathrm{M}$ phosphorus; Morel et al. 1979). The cultures were maintained indoor for at least 20 generations under a photon flux density of $100 \mu \mathrm{mol}$ photons $\mathrm{m}^{-2} \mathrm{~s}^{-1}$ (12 h:12 h light:dark period) in a plant growth chamber (GXZ, Ruihua) at a constant temperature of $20^{\circ} \mathrm{C}$ under the $2 \mathrm{CO}_{2}$ levels before being transferred to the outdoor (rooftop) growth experiments under solar radiation. The outdoor cultures were incubated in $250 \mathrm{ml}$ polyethylene bottles, which allowed 81\% PAR, 53\% UV-A (315 to $400 \mathrm{~nm}$ ) and 5\% UV-B (280 to $315 \mathrm{~nm}$ ) transmissions under incident solar radiation (determined by spectrophotometry before use). The temperature was controlled at $20^{\circ} \mathrm{C}$ using a circulating cooler (CTP3000 , Eyela). In the outdoor incubations, the cultures were diluted every $24 \mathrm{~h}$ (at 18:00 $\mathrm{h}$ before the onset of the dark phase) with freshly prepared medium equilibrated to the target $\mathrm{CO}_{2}$ levels ( $\mathrm{HC}$ and $\mathrm{LC}$ ), with the cell concentrations of about $3 \times 10^{4}$ cells ml-1 after the dilutions and of $<9 \times 10^{4}$ cells $\mathrm{ml}^{-1}$ before the dilutions. As the specific growth rates differed under different conditions, the renewed amount of the medium differed. The fresh medium pre-equilibrated at target $p \mathrm{CO}_{2}$ levels were achieved by aerating (0.5 $\left.1 \mathrm{~min}^{-1}\right)$ ambient air (outside, rooftop) or air with elevated (1000 $\mu \mathrm{atm}, \mathrm{HC}$ ) $\mathrm{CO}_{2}$ from a plant $\mathrm{CO}_{2}$ incubator (HP1000G-D, Ruihua). For strain CCMP 2090, the outdoor incubation period was from 17 April 2012 to 11 May 2012 (acclimation for at least $6 \mathrm{~d}$, followed by an experimental phase lasting $18 \mathrm{~d}$ ), with mean daily incident PAR, UVA and UVB doses of 5.3 MJ $\mathrm{m}^{-2} \mathrm{~d}^{-1}, 0.85 \mathrm{MJ} \mathrm{m}^{-2} \mathrm{~d}^{-1}$ and $26 \mathrm{~kJ} \mathrm{~m}^{-2} \mathrm{~d}^{-1}$, respectively. For strain PML B92/11, the outdoor incubation phase was from 21 May 2012 to 7 June 2012 (acclimation for at least $6 \mathrm{~d}$, experimental phase $7 \mathrm{~d}$ ), with mean daily incident PAR, UVA and UVB doses of 8.56 $\mathrm{MJ} \mathrm{m}^{-2} \mathrm{~d}^{-1}, 1.38 \mathrm{MJ} \mathrm{m}^{-2} \mathrm{~d}^{-1}$ and $41.9 \mathrm{~kJ} \mathrm{~m}^{-2} \mathrm{~d}^{-1}$, respectively (daily doses of PAR, UVA and UVB are shown in Figs. S1\& S2 in the Supplement at www.intres.com/articles/suppl/m568p047_supp.pdf). Levels of incident solar PAR were achieved with neutral density screens as follows: 6.5, 10, 17, 31 and $55 \%$ $\left(54,83,141,257\right.$ and $457 \mu \mathrm{mol}$ photons $\mathrm{m}^{-2} \mathrm{~s}^{-1}$, respectively) for strain PML B92/11; 10, 17, 31, 51 and $100 \%(57,96,176,312$, and $567 \mu \mathrm{mol}$ photons $\mathrm{m}^{-2} \mathrm{~s}^{-1}$, respectively) for strain CCMP 2090. It should be noted that we only mimicked the light intensities at different depths in the upper mixed layer; we did not take into account changes in light quality occur- ring as a result of the upwelling and downwelling of phytoplankton cells in the water column. Solar PAR and ultraviolet radiation were measured every $1 \mathrm{~s}$ with a broadband solar radiometer (ELDONET, Real Time Computer, Germany) and the averaged values over 1-min intervals were recorded.

\section{Carbonate chemistry measurements}

We were not able to measure the carbonate chemistry parameters on a daily basis. To maintain stable carbonate chemistry of the cultures, we measured the carbonate chemistry parameters before the experiments to make sure previously applied semi-continuous culture manipulation methods were reliable (Gao et al. 2012, Jin et al. 2013, Jin \& Gao 2016). Then, we ran the outdoor incubations by following the reliable protocols as tested in preliminary experiments. In addition, by keeping the cell concentrations below $9 \times 10^{4}$ cells $\mathrm{ml}^{-1}$ for most of the time, we were able to limit the total dissolved inorganic carbon (DIC) drawn down to less than $7 \%$ in line with the cultivation recommendations of LaRoche et al. 2010. It should be noted that, very occasionally, the cell concentrations were as high as $1.3 \times 10^{5}$ cells $\mathrm{ml}^{-1}$ on some days, due to relatively higher growth rates. Therefore, despite diurnal changes in the carbonate chemistry, a significant difference in carbonate system parameters was maintained between the high $\mathrm{CO}_{2}$ and low $\mathrm{CO}_{2}$ treatments.

\section{Determination of growth rates}

Cell numbers were determined by a particle counter (Z2, Beckman instruments once every $24 \mathrm{~h}$ (at 18:00 h before onset of the dark phase) before and after the partial renewal of the medium (performed in laminar flow hood). Growth rate $(\mu)$ was calculated by the following equation: $\mu=\left(\ln N_{1}-\ln N_{0}\right) /\left(t_{1}-t_{0}\right)$, where $N_{1}$ and $N_{0}$ are the numbers of cells number at time $t_{1}$ and $t_{0}\left(t_{1}-t_{0}=1 \mathrm{~d}\right)$, respectively.

\section{Carbon and nitrogen measurements}

Samples taken from each replicate culture (3 replicates for each treatment) under 5 solar radiation levels and $2 \mathrm{CO}_{2}$ conditions at the end of the outdoor incubations (on 11 May 2012 for non-calcifying strain CCMP 2090 and on 7 June 2012 for the calcifying strain PML B92/11) were filtered onto pre-combusted 
$\left(500^{\circ} \mathrm{C}\right.$ for $\left.5 \mathrm{~h}\right)$ Whatman $\mathrm{GF} / \mathrm{F}$ filters (diameter $25 \mathrm{~mm}$ ) and frozen at $-20^{\circ} \mathrm{C}$. The sampling time was also at 18:00 h. For POC and particulate organic nitrogen (PON) analysis, filters were fumed over saturated $\mathrm{HCl}$ for $24 \mathrm{~h}$ to remove all inorganic carbon. The samples were analyzed on a Perkin Elmer Series II CHNS/O Analyzer 2400. PIC was calculated as the difference between total particulate carbon (TPC) and POC.

Rates of PIC, POC and PON production were calculated as: production rate $=$ growth rate $\left(\mu, \mathrm{d}^{-1}\right) \times$ cellular PIC, POC or PON content (pg cell-1).

\section{Data analysis}

One-way ANOVA was used to establish differences among the treatments $(p<0.05)$. Two-way ANOVA was used to determine the individual effects of $\mathrm{CO}_{2}$ and solar radiation levels and their interactions.

\section{RESULTS}

\section{Growth}

In general, elevated $p \mathrm{CO}_{2}$ enhanced the growth of both strains (2-way ANOVA, calcifying strain PML B92/11: df =1, F=81.276, p < 0.001; non-calcifying strain CCMP 2090: df $=1, F=17.809$, p < 0.001) (Tables $1 \& 2$, Fig. 1). Elevated $p \mathrm{CO}_{2}$ stimulated growth by 15 to $24 \%$ in the calcifying strain and by 22 to $28 \%$ in the non-calcifying strain with higher stimulation at higher solar radiation levels (Fig. 1). Specifically, in the calcifying strain, growth rates of the HC-grown cells were 15, 16, 24 and $24 \%$ higher than that of the LC-grown cells at $10,17,31$ and 55 of incident solar radiation, respectively (Fig. 1a). A significant interaction between $O A$ and solar radiation was found for the calcifying strain, suggesting that elevated $\mathrm{CO}_{2}$ and increasing solar radiation were acting synergistically to enhance the growth in this strain (2-way

Table 1. Responses of calcifying strain PML B92/11 and non-calcifying strain CCMP 2090 of Emiliania huxleyi grown under ambient (low $\mathrm{CO}_{2}[\mathrm{LC}] 395 \mu \mathrm{atm}$ ) and increased (high $\left.\mathrm{CO}_{2}[\mathrm{HC}] 1000 \mu \mathrm{atm}\right) \mathrm{CO}_{2}$ conditions under different solar radiation levels (shown as percent of incident PAR and flux in $\mu$ mol photons $\left.\mathrm{m}^{-2} \mathrm{~s}^{-1}\right)$. Responses measured were specific growth rate $\mu\left(\mathrm{d}^{-1}\right)$, content $\left(\mathrm{pg}\right.$ cell $\left.{ }^{-1}\right)$ and production (pg cell ${ }^{-1} \mathrm{~d}^{-1}$ ) of particulate organic carbon (POC), particulate organic nitrogen (PON) and particulate inorganic carbon (PIC), and PIC:POC and C:N ratios (pg pg $\left.{ }^{-1}\right) . \mu_{E}$ and $\mu_{S}$ represent the specific growth rate during the whole experimental phase (7 d for PML B92/11, $18 \mathrm{~d}$ for CCMP 2090) and on the PIC, POC and PON sampling day (PML B92/11: 7 June 2012; CCMP 2090: 11 May 2012), respectively. Values are mean $\pm \mathrm{SD}(\mathrm{n}=3)$. nd: no data

\begin{tabular}{|c|c|c|c|c|c|c|c|c|c|c|c|}
\hline \multirow{2}{*}{\multicolumn{2}{|c|}{$\begin{array}{l}\text { Solar radiation leve } \\
\% \quad \text { Flux }\end{array}$}} & \multirow{2}{*}{$\mu_{\mathrm{E}}$} & \multirow{2}{*}{$\mu_{\mathrm{S}}$} & \multicolumn{2}{|c|}{ POC } & \multicolumn{2}{|c|}{ PON } & \multicolumn{2}{|c|}{ PIC } & \multirow{2}{*}{ PIC:POC } & \multirow{2}{*}{$\mathrm{C}: \mathrm{N}$} \\
\hline & & & & Content & Prod. & Content & Prod. & Content & Prod. & & \\
\hline \multicolumn{12}{|c|}{ Calcifying-HC } \\
\hline 6.5 & $54 \pm 17$ & $0.59 \pm 0.11$ & $0.59 \pm 0.02$ & $16.9 \pm 0.8$ & $10.0 \pm 0.8$ & $2.1 \pm 0.1$ & $1.3 \pm 0.1$ & $3.4 \pm 0.2$ & $2.0 \pm 0.1$ & $0.2 \pm 0.02$ & $9.3 \pm 0.3$ \\
\hline 10 & $83 \pm 26$ & $0.62 \pm 0.12$ & $0.72 \pm 0.05$ & $15.6 \pm 1.1$ & $11.3 \pm 1.3$ & $2.1 \pm 0.2$ & $1.5 \pm 0.2$ & $4.2 \pm 0.5$ & $3.0 \pm 0.2$ & $0.3 \pm 0.05$ & $8.6 \pm 0.6$ \\
\hline 17 & $141 \pm 45$ & $0.66 \pm 0.08$ & $0.77 \pm 0.00$ & $16.1 \pm 1.0$ & $12.4 \pm 0.8$ & $2.4 \pm 0.4$ & $1.8 \pm 0.3$ & $5.1 \pm 0.8$ & $4.0 \pm 0.6$ & $0.3 \pm 0.04$ & $8.0 \pm 1.0$ \\
\hline 31 & $257 \pm 82$ & $0.64 \pm 0.13$ & $0.80 \pm 0.04$ & $17.2 \pm 2.7$ & $13.8 \pm 2.7$ & $2.3 \pm 0.4$ & $1.9 \pm 0.4$ & $4.1 \pm 0.9$ & $4.1 \pm 0.9$ & $0.3 \pm 0.07$ & $8.6 \pm 1.5$ \\
\hline 55 & $456 \pm 145$ & $0.62 \pm 0.16$ & $0.85 \pm 0.07$ & $21.1 \pm 2.9$ & $18.0 \pm 3.8$ & $2.8 \pm 0.5$ & $2.4 \pm 0.5$ & $3.8 \pm 0.7$ & $3.2 \pm 0.7$ & $0.2 \pm 0.05$ & $8.9 \pm 1.5$ \\
\hline \multicolumn{12}{|c|}{ Calcifying-LC } \\
\hline 6.5 & $54 \pm 17$ & $0.62 \pm 0.10$ & $0.60 \pm 0.04$ & $14.0 \pm 1.4$ & $8.5 \pm 0.4$ & $2.0 \pm 0.4$ & $1.2 \pm 0.2$ & $8.5 \pm 1.0$ & $5.1 \pm 0.4$ & $0.6 \pm 0.07$ & $8.5 \pm 0.9$ \\
\hline 10 & $83 \pm 26$ & $0.73 \pm 0.09$ & $0.65 \pm 0.13$ & $16.5 \pm 2.6$ & $10.5 \pm 0.3$ & $2.1 \pm 0.7$ & $1.4 \pm 0.3$ & $7.8 \pm 1.9$ & $5.0 \pm 0.9$ & $0.5 \pm 0.09$ & $9.3 \pm 1.6$ \\
\hline 17 & $141 \pm 45$ & $0.78 \pm 0.06$ & $0.64 \pm 0.12$ & $16.0 \pm 0.7$ & $10.2 \pm 0.9$ & $2.0 \pm 0.2$ & $1.3 \pm 0.1$ & $8.5 \pm 0.9$ & $5.4 \pm 0.9$ & $0.5 \pm 0.07$ & $9.4 \pm 0.9$ \\
\hline 31 & $257 \pm 82$ & $0.84 \pm 0.08$ & $0.68 \pm 0.10$ & $17.9 \pm 1.9$ & $12.3 \pm 2.6$ & $2.1 \pm 0.3$ & $1.5 \pm 0.3$ & $8.8 \pm 2.6$ & $5.9 \pm 1.0$ & $0.5 \pm 0.2$ & $9.8 \pm 1.5$ \\
\hline 55 & $456 \pm 145$ & $0.81 \pm 0.08$ & $0.57 \pm 0.12$ & $19.1 \pm 2.8$ & $10.7 \pm 0.9$ & $2.1 \pm 0.3$ & $1.2 \pm 0.0$ & $5.5 \pm 1.2$ & $3.1 \pm 1.0$ & $0.3 \pm 0.1$ & $10.7 \pm 0.8$ \\
\hline \multicolumn{12}{|c|}{ Non-calcifying-HC } \\
\hline 10 & $57 \pm 30$ & $0.50 \pm 0.26$ & $0.40 \pm 0.03$ & $6.3 \pm 0.7$ & $2.6 \pm 0.4$ & $1.2 \pm 0.2$ & $0.5 \pm 0.1$ & nd & nd & nd & $6.1 \pm 0.4$ \\
\hline 17 & $96 \pm 52$ & $0.57 \pm 0.25$ & $0.47 \pm 0.37$ & $4.9 \pm 0.8$ & $2.3 \pm 1.2$ & $1.0 \pm 0.2$ & $0.5 \pm 0.3$ & nd & nd & nd & $5.7 \pm 0.2$ \\
\hline 31 & $176 \pm 95$ & $0.71 \pm 0.34$ & $0.51 \pm 0.13$ & $5.4 \pm 0.8$ & $2.7 \pm 1.6$ & $1.2 \pm 0.1$ & $0.6 \pm 0.1$ & nd & nd & nd & $5.4 \pm 0.6$ \\
\hline 55 & $312 \pm 168$ & $0.77 \pm 0.30$ & $0.89 \pm 0.10$ & $5.2 \pm 0.2$ & $4.6 \pm 0.7$ & $1.1 \pm 0.1$ & $1.0 \pm 0.1$ & nd & nd & nd & $5.4 \pm 0.2$ \\
\hline 100 & $567 \pm 305$ & $0.72 \pm 0.29$ & $0.76 \pm 0.14$ & $7.4 \pm 0.9$ & $5.7 \pm 1.8$ & $1.3 \pm 0.2$ & $1.0 \pm 0.2$ & nd & nd & nd & $6.9 \pm 1.4$ \\
\hline \multicolumn{12}{|c|}{ Non-calcifying-LC } \\
\hline 10 & $57 \pm 30$ & $0.36 \pm 0.17$ & $0.14 \pm 0.07$ & $6.7 \pm 1.4$ & $0.9 \pm 0.3$ & $0.8 \pm 0.2$ & $0.1 \pm 0.0$ & nd & nd & nd & $9.6 \pm 1.2$ \\
\hline 17 & $96 \pm 52$ & $0.44 \pm 0.15$ & $0.26 \pm 0.06$ & $5.7 \pm 1.3$ & $1.5 \pm 0.2$ & $0.7 \pm 0.1$ & $0.2 \pm 0.0$ & nd & nd & nd & $9.6 \pm 0.9$ \\
\hline 31 & $176 \pm 95$ & $0.50 \pm 0.16$ & $0.30 \pm 0.13$ & $5.5 \pm 0.3$ & $1.6 \pm 0.5$ & $0.8 \pm 0.0$ & $0.2 \pm 0.1$ & nd & nd & nd & $7.7 \pm 1.1$ \\
\hline 55 & $312 \pm 168$ & $0.57 \pm 0.16$ & $0.44 \pm 0.04$ & $5.9 \pm 1.0$ & $2.6 \pm 0.6$ & $0.8 \pm 0.2$ & $0.4 \pm 0.1$ & nd & nd & nd & $8.7 \pm 0.9$ \\
\hline 100 & $567 \pm 305$ & $0.52 \pm 0.20$ & $0.41 \pm 0.02$ & $6.0 \pm 0.9$ & $2.5 \pm 0.5$ & $0.9 \pm 0.3$ & $0.4 \pm 0.1$ & nd & nd & nd & $8.5 \pm 1.4$ \\
\hline
\end{tabular}




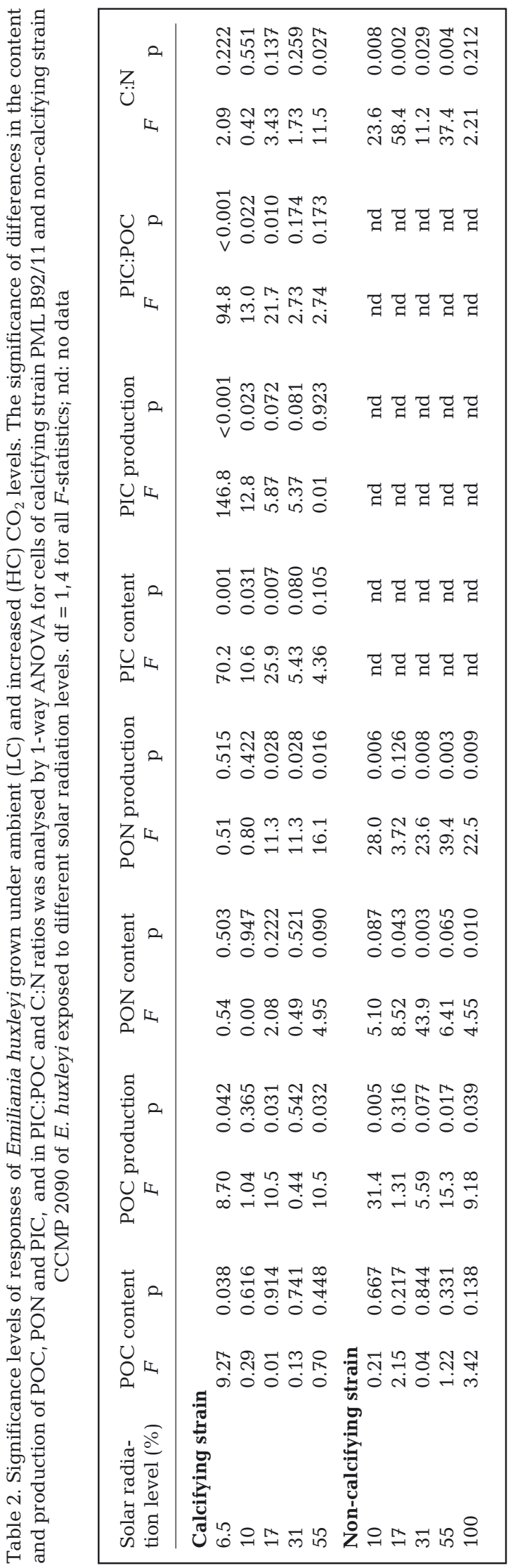
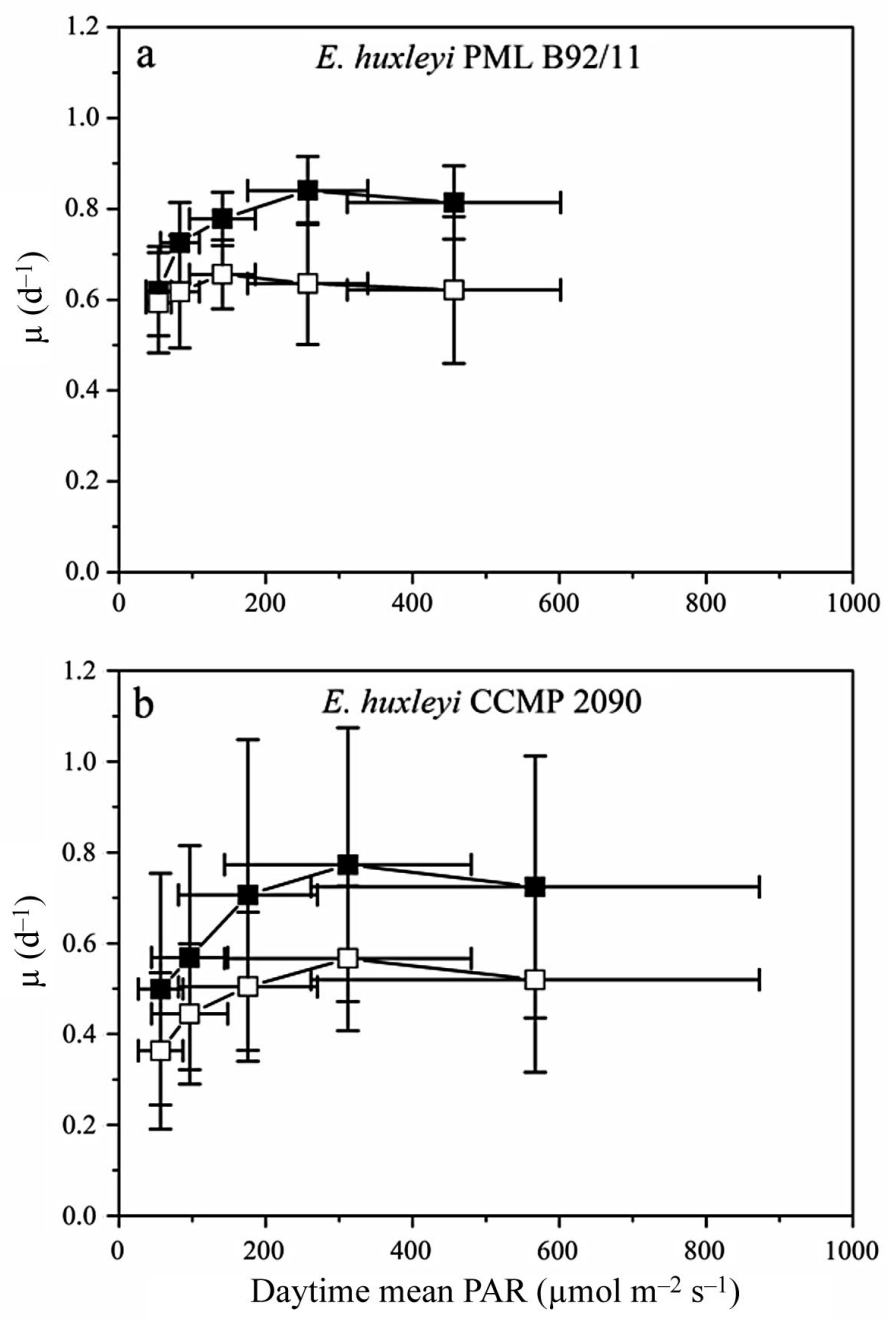

Fig. 1. Growth rates $(\mu)$ of Emiliania huxleyi grown under

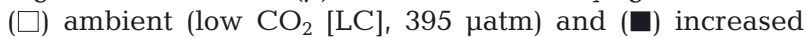
(high $\mathrm{CO}_{2}$ [HC], $\left.1000 \mu \mathrm{atm}\right) \mathrm{CO}_{2}$ conditions: (a) calcifying strain PML B92/11 under 6.5, 10, 17, 31, 55\% levels of incident solar radiation; (b) non-calcifying strain CCMP 2090 under 10, 17, 31, 55 and $100 \%$ levels of incident solar radiation. Values are mean \pm SD for replicate cultures $(n=3)$ in outdoor experimental phases ( $7 \mathrm{~d}$ for strain PML B92/11 and $18 \mathrm{~d}$ for strain CCMP 2090). Horizontal and vertical error bars denote standard deviations for variation of solar radiation and $\mu$, respectively

ANOVA, df $=4, F=4.996, p<0.001$ ) (Fig. 1a, Tables $1 \& 2$ ). For the non-calcifying strain, growth rates were $27.2,21.8,28.6,26.7$ and 28.2 higher in the HC-grown cells at 10,17, 31, 55 and $100 \%$ of incident solar radiation, respectively (Fig. 1b). No significant interaction between the solar radiation and $\mathrm{CO}_{2}$ levels was found in this strain (2-way ANOVA, df $=4, F=0.802, p=0.524$; Fig. $1 \mathrm{~b}$, Tables 1 \& 2). 


\section{Cellular POC content and POC production rate}

Elevated $\mathrm{CO}_{2}$ did not affect the cellular POC in the calcifying strain (2-way ANOVA, df $=1, F=0.838, \mathrm{p}=$ 0.371 ; Fig. 2a) or the non-calcifying strain (2-way ANOVA, df =1, $F=0.143, \mathrm{p}=0.709$; Fig. 2c, Tables 1 $\& 2)$. Moreover, there was no consistent difference in cellular POC content across the different solar radiation levels (Fig. 2a,c). Due to the $\mathrm{CO}_{2}$-stimulated growth rate, calculated POC production was significantly higher in HC-grown compared to LC-grown cells (Fig. 2b,d, Table 3), and the increment increased within the solar radiation levels (e.g. for the calcifying strain there was an increment of $25 \%$ at the $6.5 \%$ light level, and an increment of $44 \%$ at the $55 \%$ light level) (Table 3 ). In both strains, POC production increased with increasing solar radiation, with a slope of $0.016\left(n=5, R^{2}=0.98\right)$ and $0.004(n=$
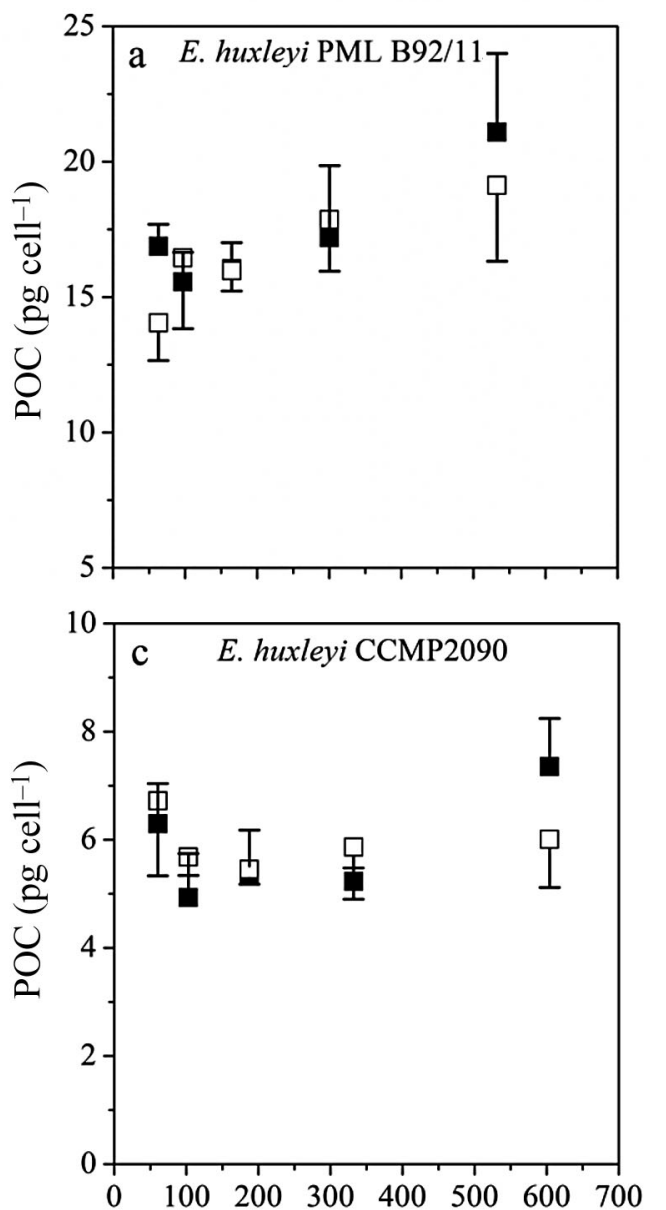

Daytime mean PAR $\left(\mu \mathrm{mol} \mathrm{m} \mathrm{m}^{-2} \mathrm{~s}^{-1}\right)$ $\left.5, \mathrm{R}^{2}=0.26\right)$, respectively, in the HC- and LC-grown calcifying strain (Fig. 2b), and a slope of $0.007(\mathrm{n}=5$, $\left.\mathrm{R}^{2}=0.92\right)$ and $0.003\left(\mathrm{n}=5, \mathrm{R}^{2}=0.73\right)$, respectively, in the HC- and LC-grown non-calcifying strain (Fig. 2d). There was a significant interaction between $\mathrm{CO}_{2}$ and solar radiation on $\mathrm{POC}$ production in the calcifying strain, suggesting that elevated $\mathrm{CO}_{2}$ and increasing solar radiation acted synergistically to enhance the POC production (2-way ANOVA, df $=4, F=3.212$, $\mathrm{p}=0.034$; Fig. 2d, Tables 1 \& 2).

\section{Cellular PON content and PON production rate}

Similar to the cellular POC content, no consistent change with solar radiation intensity was observed in cellular PON content (Fig. 3). However, in both strains the cellular PON content was higher in HC-
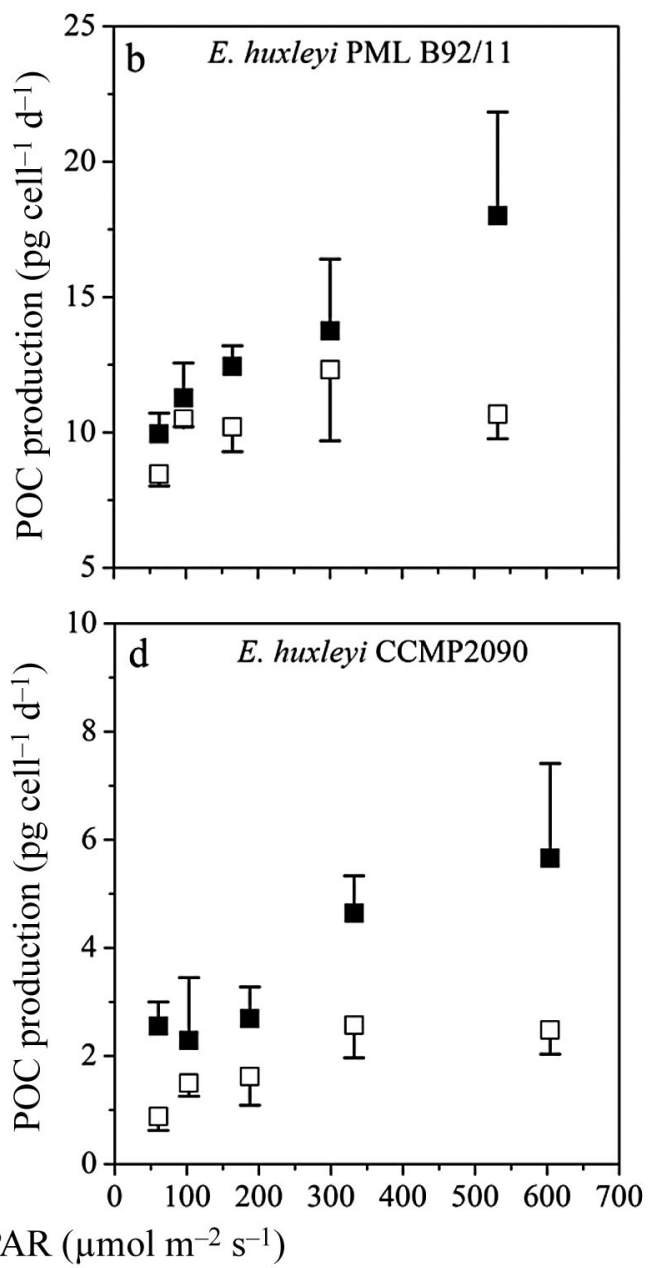

Fig. 2. Particulate organic carbon (POC, pg cell ${ }^{-1}$ ) and POC production rates $\left(\mathrm{pg} \mathrm{cell}^{-1} \mathrm{~d}^{-1}\right.$ ) of Emiliania huxleyi grown under $(\square)$ ambient (LC) and ( $\square$ ) increased (HC) $\mathrm{CO}_{2}$ conditions and different solar radiation levels: (a) POC cell content and (b) production rates for calcifying strain PML B92/11; (c) cell content and (d) production rates for non-calcifying strain CCMP 2090. Values are mean and SD $(\mathrm{n}=3)$ 
Table 3. Two-way ANOVA analysis of individual and interactive effects of $p \mathrm{CO}_{2}$ and solar radiation (SR) on growth, cell content and production of POC, PON and PIC, and PIC:POC and C:N ratios in calcifying strain PML B92/11 and non-calcifying strain CCMP 2090 of Emiliania huxleyi

\begin{tabular}{|c|c|c|c|c|}
\hline Parameter & Treatment & df & $F$ & $\mathrm{p}$ \\
\hline \multicolumn{5}{|l|}{ Calcifying strain } \\
\hline \multirow[t]{3}{*}{ Growth } & $p \mathrm{CO}_{2}$ & 1 & 81.276 & $<0.001$ \\
\hline & $\mathrm{SR}$ & 4 & 10.675 & $<0.001$ \\
\hline & $p \mathrm{CO}_{2} \times \mathrm{SR}$ & 4 & 4.996 & $<0.001$ \\
\hline \multirow{3}{*}{ POC content } & $p \mathrm{CO}_{2}$ & 1 & 0.838 & 0.371 \\
\hline & $\mathrm{SR}$ & 4 & 5.462 & 0.004 \\
\hline & $p \mathrm{CO}_{2} \times \mathrm{SR}$ & 4 & 1.042 & 0.411 \\
\hline \multirow[t]{3}{*}{ POC production } & $p \mathrm{CO}_{2}$ & 1 & 15.891 & $<0.001$ \\
\hline & $\mathrm{SR}$ & 4 & 7.113 & $<0.001$ \\
\hline & $p \mathrm{CO}_{2} \times \mathrm{SR}$ & 4 & 3.212 & 0.034 \\
\hline \multirow[t]{3}{*}{ PON content } & $p \mathrm{CO}_{2}$ & 1 & 4.437 & 0.048 \\
\hline & SR & 4 & 1.019 & 0.421 \\
\hline & $p \mathrm{CO}_{2} \times \mathrm{SR}$ & 4 & 0.864 & 0.503 \\
\hline \multirow[t]{3}{*}{ PON production } & $p \mathrm{CO}_{2}$ & 1 & 24.399 & $<0.001$ \\
\hline & $\mathrm{SR}$ & 4 & 3.831 & 0.018 \\
\hline & $p \mathrm{CO}_{2} \times \mathrm{SR}$ & 4 & 4.168 & 0.013 \\
\hline \multirow[t]{3}{*}{$\mathrm{C}: \mathrm{N}$} & $p \mathrm{CO}_{2}$ & 1 & 6.214 & 0.022 \\
\hline & SR & 4 & 1.280 & 0.311 \\
\hline & $p \mathrm{CO}_{2} \times \mathrm{SR}$ & 4 & 1.780 & 0.172 \\
\hline \multirow[t]{3}{*}{ PIC content } & $p \mathrm{CO}_{2}$ & 1 & 58.205 & $<0.001$ \\
\hline & $\mathrm{SR}$ & 4 & 3.325 & 0.030 \\
\hline & $p \mathrm{CO}_{2} \times \mathrm{SR}$ & 4 & 1.343 & 0.289 \\
\hline \multirow[t]{3}{*}{ PIC production } & $p \mathrm{CO}_{2}$ & 1 & 36.994 & $<0.001$ \\
\hline & $\mathrm{SR}$ & 4 & 6.367 & 0.002 \\
\hline & $p \mathrm{CO}_{2} \times \mathrm{SR}$ & 4 & 3.475 & 0.026 \\
\hline \multirow[t]{3}{*}{ PIC:POC } & $p \mathrm{CO}_{2}$ & 1 & 47.613 & $<0.001$ \\
\hline & $\mathrm{SR}$ & 4 & 4.177 & 0.013 \\
\hline & $p \mathrm{CO}_{2} \times \mathrm{SR}$ & 4 & 2.015 & 0.131 \\
\hline \multicolumn{5}{|c|}{ Non-calcifying strain } \\
\hline \multirow[t]{3}{*}{ Growth } & $p \mathrm{CO}_{2}$ & 1 & 17.809 & $<0.001$ \\
\hline & SR & 4 & 72.758 & $<0.001$ \\
\hline & $p \mathrm{CO}_{2} \times \mathrm{SR}$ & 4 & 0.802 & 0.524 \\
\hline \multirow[t]{3}{*}{ POC content } & $p \mathrm{CO}_{2}$ & 1 & 0.143 & 0.709 \\
\hline & $\mathrm{SR}$ & 4 & 3.875 & 0.017 \\
\hline & $p \mathrm{CO}_{2} \times \mathrm{SR}$ & 4 & 1.647 & 0.202 \\
\hline \multirow[t]{3}{*}{ POC production } & $p \mathrm{CO}_{2}$ & 1 & 35.928 & $<0.001$ \\
\hline & SR & 4 & 10.753 & $<0.001$ \\
\hline & $p \mathrm{CO}_{2} \times \mathrm{SR}$ & 4 & 2.051 & 0.126 \\
\hline \multirow[t]{3}{*}{ PON content } & $p \mathrm{CO}_{2}$ & 1 & 34.034 & $<0.001$ \\
\hline & $\mathrm{SR}$ & 4 & 1.233 & 0.329 \\
\hline & $p \mathrm{CO}_{2} \times \mathrm{SR}$ & 4 & 0.091 & 0.984 \\
\hline \multirow[t]{3}{*}{ PON production } & $p \mathrm{CO}_{2}$ & 1 & 87.031 & $<0.001$ \\
\hline & SR & 4 & 10.781 & $<0.001$ \\
\hline & $p \mathrm{CO}_{2} \times \mathrm{SR}$ & 4 & 2.174 & 0.109 \\
\hline \multirow[t]{3}{*}{$C: N$} & $p \mathrm{CO}_{2}$ & 1 & 76.981 & $<0.001$ \\
\hline & $\mathrm{SR}$ & 4 & 2.017 & 0.131 \\
\hline & $p \mathrm{CO}_{2} \times \mathrm{SR}$ & 4 & 1.488 & 0.243 \\
\hline
\end{tabular}

compared to LC-grown cells, although differences were not statistically significant for most solar radiation intensities in the calcifying strain (Fig. 3a,c, Table 3). In combination with the higher growth rates, this increase in PON content equates to much higher PON production rates in HC-grown cells, with a maximum increment at the highest solar radiation level $(100 \%)$ in the calcifying strain and a maximum increment at the solar radiation level of $31 \%$ in the non-calcifying strain (Fig. 3b,d, Table 3). PON production increased with increasing solar radiation intensity in HC- and LC-grown cells of both strains. Elevated $\mathrm{CO}_{2}$ and increasing solar radiation apparently acted synergistically to enhance the PON production in the calcifying strain (2-way ANOVA, df = $4, F=4.168, p=0.013$; Fig. 3b, Tables $1 \& 2$ ).

\section{$\mathrm{C}: \mathrm{N}$ ratio}

Elevated $\mathrm{CO}_{2}$ significantly decreased the $\mathrm{C}: \mathrm{N}$ ratio in both strains. C:N ratios decreased by 7 to $17 \%$ (2way ANOVA, $\mathrm{df}=1, F=6.214, \mathrm{p}=0.022$ ) in the calcifying strain and by 20 to $41 \%$ (2-way ANOVA, df = $1, F=76.981, \mathrm{p}<0.001$ ) in the non-calcifying strain at different solar radiation levels; however, there was no significant effect of solar radiation on $\mathrm{C}: \mathrm{N}$ ratio in either strain (2-way ANOVA, all $\mathrm{df}=1$, both $\mathrm{p}>0.05$; for detailed results see Table 3) (Fig. 4). In addition, no significant interaction between $\mathrm{CO}_{2}$ and solar radiation on $\mathrm{C}: \mathrm{N}$ ratio was observed in either strain (2-way ANOVA, all $\mathrm{df}=4$, all $\mathrm{p}>0.05$; for detailed results see Table 3) (Fig. 4).

\section{Cellular PIC content, PIC production and PIC:POC}

Elevated $\mathrm{CO}_{2}$ significantly decreased the cellular PIC content of the calcifying strain by 42 to $63 \%$ at low solar radiation levels of 6.5 to $17 \%$ (Fig. $5 \mathrm{a}$, Table 3 ), while no significant differences were found at the high solar radiation levels of 31 and $55 \%$ (1-way ANOVA, $31 \%: F_{1,4}=5.43, \mathrm{p}=0.080 ; 55 \%: F_{1,4}=4.36$, $\mathrm{p}=0.105$ ). PIC production rates were significantly lower in HC- compared to LC-grown cells, falling by 40 and $60 \%$ at solar radiation levels of 17 and $6.5 \%$, respectively (Fig. 5b, Table 3). Similar to cellular PIC content, the PIC:POC ratio decreased significantly, by 43 to $72 \%$, at low solar radiation levels of 6.5 to $17 \%$ in HC-grown cells (Fig. 5c, Table 3), while PIC:POC in HC-grown cells did not differ from that in LC-grown cells at the high solar radiation levels of 31 and $55 \%$ (Fig. 5c, Table 3). Elevated $\mathrm{CO}_{2}$, however, had significant negative effects on cellular PIC content, PIC production and PIC:POC, and a significant interaction between $\mathrm{CO}_{2}$ and solar radiation was found in PIC production, suggesting an antagonistic effect of $\mathrm{OA}$ and increasing solar radiation (2-way ANOVA, $\mathrm{df}=4, F=3.475, \mathrm{p}=0.026$ ). 

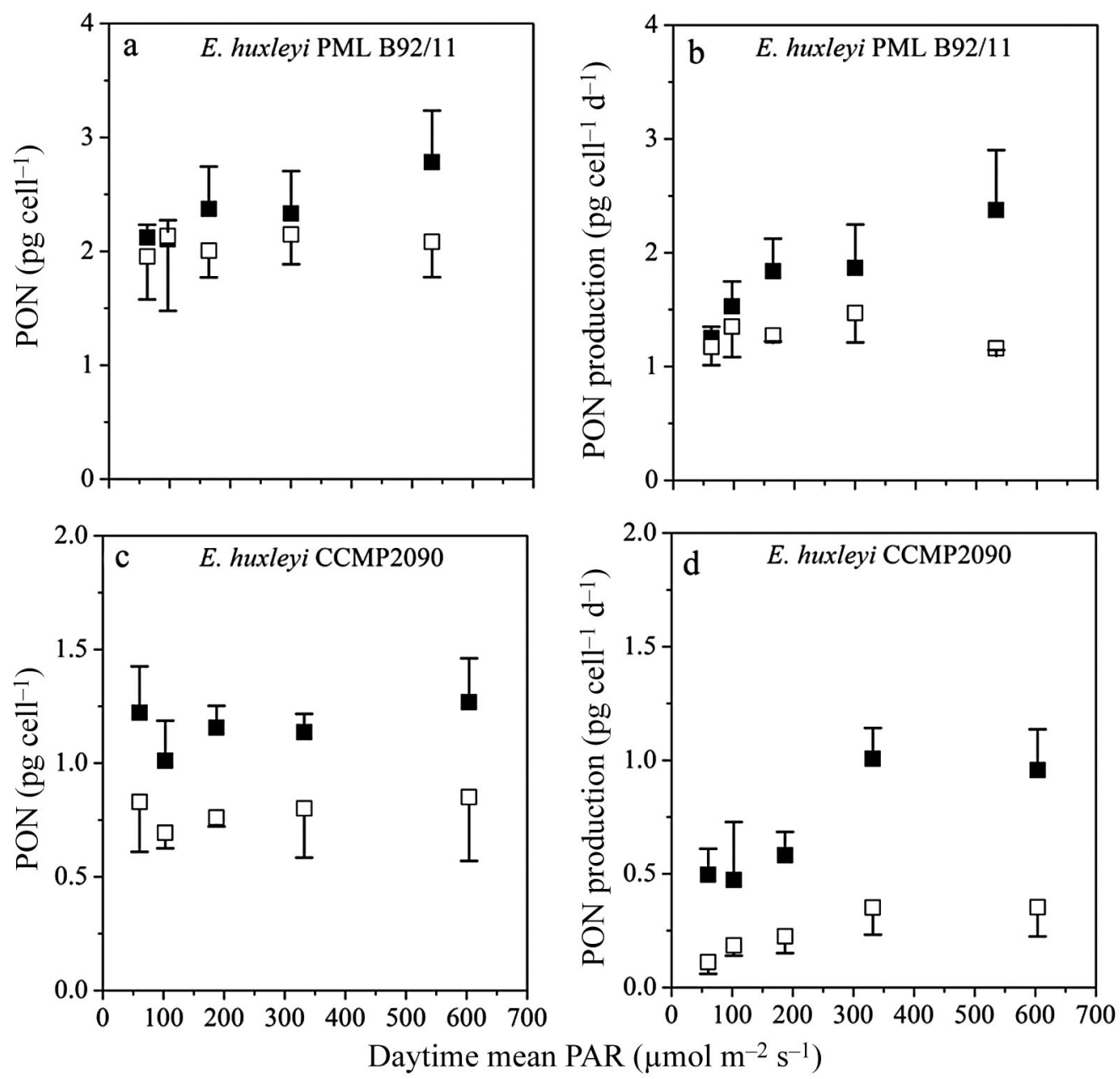

Fig. 3. Particulate organic nitrogen (PON, pg cell ${ }^{-1}$ ) and PON production rates $\left(\mathrm{pg} \mathrm{cell}^{-1} \mathrm{~d}^{-1}\right.$ ) of Emiliania huxleyi grown under $(\square)$ ambient (LC) and ( $\square$ ) increased (HC) $\mathrm{CO}_{2}$ conditions and different solar radiation levels: (a) PON cell content and (b) production rates for calcifying strain PML B92/11; (c) cell content and (d) production rates for non-calcifying strain CCMP 2090.

Values are mean and SD $(n=3)$

\section{DISCUSSION}

Our study investigated the interactive effects of OA and increasing solar radiation on the physiology of a calcifying strain (PML B92/11) and a non-calcifying strain (CCMP 2090) of the coccolithophore Emiliania huxleyi. We found that, firstly, OA and increased solar radiation density acted synergistically to enhance growth in the calcifying but not in the noncalcifying strain; secondly, the enhancement of POC and PON production under OA increased with increased solar radiation levels; and thirdly, OA had a negative effect on calcification at low solar radiation levels, which was absent at high solar radiation levels. These results support our hypothesis that high levels of solar radiation can offset the impacts of ocean acidification on E. huxleyi.
Increased $p \mathrm{CO}_{2}$ and associated seawater chemical changes were reported to have diverse effects on the growth of coccolithophores (Meyer \& Riebesell 2015 and references therein), due to species- and strainspecific differences, different methodologies applied as well as different experimental conditions. Our data suggest that increased $\mathrm{CO}_{2}$ could enhance growth in both a calcifying and non-calcifying strain of E. huxleyi under naturally fluctuating solar irradiance (Fig. 1, Table 2), in agreement with previous work on this species (e.g. Langer et al. 2009, Shi et al. 2009, Fiorini et al. 2011), although it should be borne in mind that only constant light was employed in previous studies. Furthermore, the enhancements of elevated $\mathrm{CO}_{2}$ on POC and PON production were higher under high solar radiation compared with low solar radiation conditions (Figs. 2 \& 3 ). This may be 

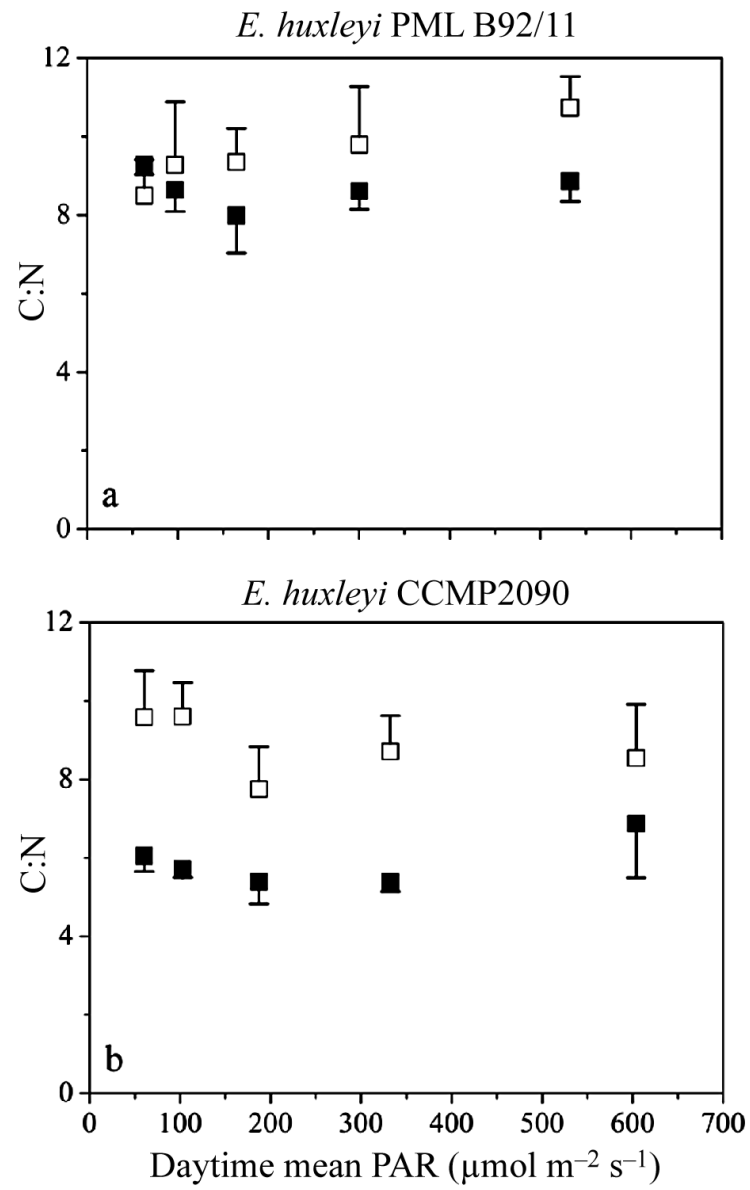

Fig. 4. C:N ratios of particulate organic carbon (POC) to particulate organic nitrogen (PON) in Emiliania huxleyi grown under ( $\square$ ) ambient (LC) and ( $\square$ ) increased (HC) $\mathrm{CO}_{2}$ conditions and different solar radiation levels: (a) calcifying strain PML B92/11; (b) non-calcifying strain CCMP 2090. Values are mean and $\mathrm{SD}(\mathrm{n}=3)$

due to the additional energetic cost of calcification in the calcifying species under low solar radiation conditions counteracting the positive effect of elevated $\mathrm{CO}_{2}$ on POC and PON production, leading to the lower POC and PON production in the HC-grown compared to LC-grown cells. Furthermore, $\left[\mathrm{H}^{+}\right]$in the cytosol of the coccolithophore E. huxleyi has been found to increase instantly (within $<10 \mathrm{~s}$ ) with increasing $\left[\mathrm{H}^{+}\right]$in seawater (Suffrian et al. 2011), which could affect POC production (Bach et al. 2011). Consequently, extra energy would be required to maintain the cell's homeostasis or net $\mathrm{H}^{+}$efflux (Jin et al. 2015), thus less energy would be available for for POC and PON production. However, when the energy availability increases under relatively high solar radiation conditions, increased availability of light could meet the demand of increased energy requirement for calcification and for $\mathrm{H}^{+}$homeostasis
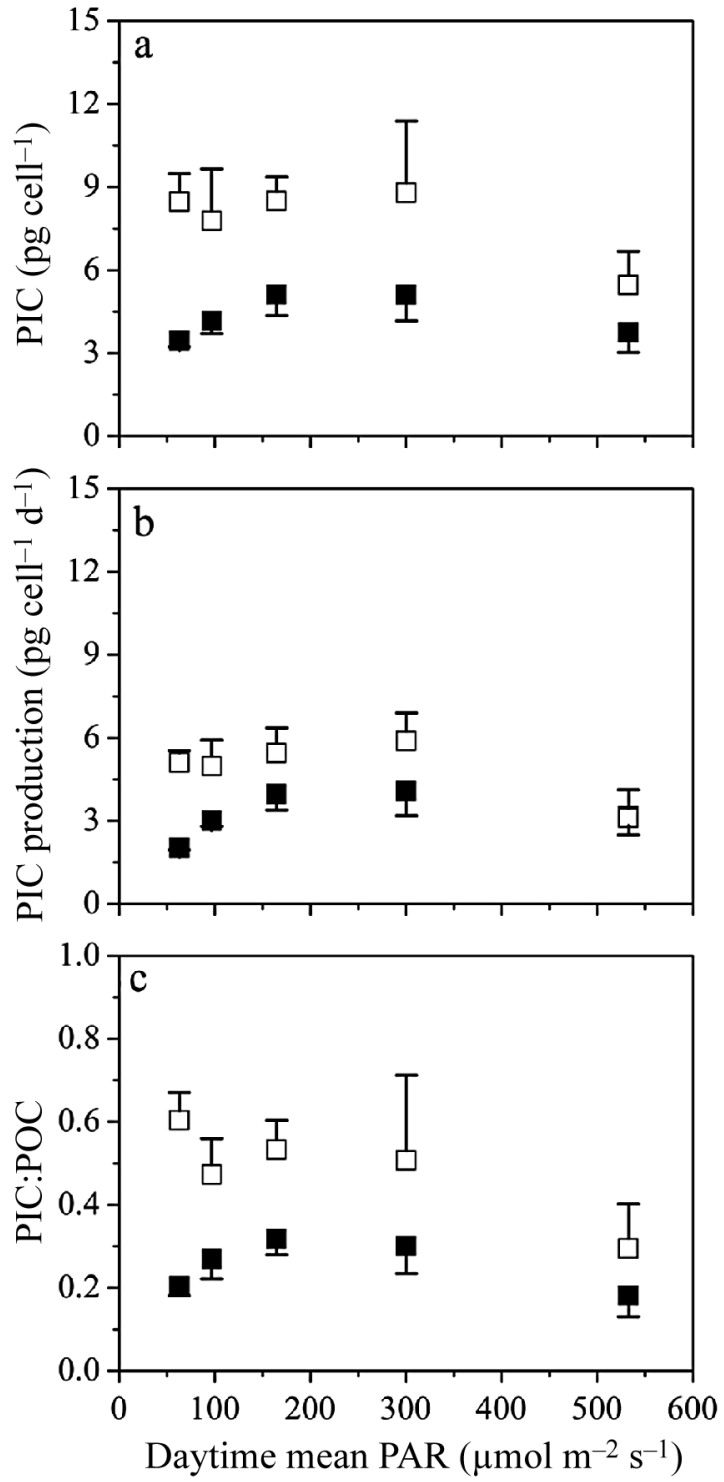

Fig. 5. (a) Particulate inorganic carbon (PIC, pg cell ${ }^{-1}$ ) (b), PIC production rates (pg cell ${ }^{-1} \mathrm{~d}^{-1}$ ) and (c) PIC:POC ratios in the calcifying strain PML B92/11 of Emiliania huxleyi, grown under ( $\square$ ) ambient (LC) and (ם) increased (LC) $\mathrm{CO}_{2}$ conditions and different solar radiation levels. Values are mean and $\mathrm{SD}(\mathrm{n}=3)$

(Rokitta \& Rost 2012). Thus, POC and PON production benefited from the $\mathrm{CO}_{2}$ increase under high solar radiation conditions, and these effects were more pronounced at increased solar radiation levels (Figs. 2 \& 3). OA and increasing solar radiation levels acted synergistically to increase POC and PON production in the calcifying but not in the non-calcifying strain (Fig. $2 \& 3$, Table 3), suggesting that the calcifying strain will benefit more in terms of increased capacity for carbon and nitrogen assimilation under future high $\mathrm{CO}_{2}$ and high light conditions; however, 
the corresponding mechanisms have not yet been determined. While PON production was more upregulated than POC production under OA conditions, a decrease of $\mathrm{C}: \mathrm{N}$ was observed in the HCgrown cells (Fig. 4). This is in good agreement with results obtained for another coccolithophore, Gephyrocapsa oceania, in which C:N decreased by $13 \%$ after the cells had been grown under OA conditions for 670 generations (Jin et al. 2013). The gene for nitrite reductase in phytoplankton can be upregulated under OA conditions (Li et al. 2017); this would enhance inorganic nitrogen uptake, leading to an increased PON quota and a decreased C:N ratio, as observed in this study (Fig. 4).

Several strains of E. huxleyi probably operate $\mathrm{CO}_{2}$ concentrating mechanisms (CCMs) (Sikes \& Wheeler 1982, Nielsen 1995, Stojkovic et al. 2013), which are likely to be down-regulated at elevated $\mathrm{CO}_{2}$ conditions (Stojkovic et al. 2013). Since the operation of CCMs is energetically costly (Raven et al. 2014), the energy saved from CCM down-regulation at elevated $\mathrm{CO}_{2}$ could be reallocated to other physiological processes, thereby resulting in increased POC and PON production (Figs. 2b,d \& 3b,d), which is in good agreement with some previous studies (Riebesell et al. 2000, Iglesias-Rodriguez et al. 2008, Shi et al. 2009, Rokitta \& Rost 2012). POC production of marine phytoplankton usually increases with increasing light intensity but decreases at extremely high light levels. However, POC production did not show any decline in either strain, even at the highest light density applied in the present study (Fig. 2b,d). This results provides a physiological basis for the E. huxleyi bloom that usually occurs in stratified water under high light intensity (Tyrrell \& Taylor 1996).

Calcification is an energy dependent process and normally decreases in coccolithophores under elevated $\mathrm{CO}_{2}$ conditions (Riebesell et al. 2000, Feng et al. 2008, Gao et al. 2009, Rokitta \& Rost 2012, present study). However, we found that OA decreased calcification at low solar radiation levels while no significant differences were detected at high solar radiation levels (Fig. 5a), suggesting the high levels of solar radiation can offset the impacts of ocean acidification on calcification in E. huxleyi. This is in agreement with some previous studies that report a decreased PIC quota with elevated $\mathrm{CO}_{2}$ under low light (e.g. $50 \mu \mathrm{mol}$ photons $\mathrm{m}^{-2} \mathrm{~s}^{-1}$ ), but not under high light (e.g. $300 \mu \mathrm{mol}$ photons $\mathrm{m}^{-2} \mathrm{~s}^{-1}$ ) (Zondervan et al. 2002, Rokitta \& Rost 2012). Elevated $\mathrm{CO}_{2}$ increases the costs of calcification (Irie et al. 2010, Raven 2011, Raven \& Crawfurd 2012), thereby lowering available energy and reducing calcification at low light levels.
However, this elevated $\mathrm{CO}_{2}$ impact may be minimized by increased energy availability under high light (Rokitta \& Rost 2012). In this study, E. huxleyi cells showed a similar response of calcification to OA as those in the previous works (e.g. Rokitta \& Rost 2012), despite being exposed to higher light levels and diel fluctuations of solar radiation in the presence of UVR. The possible reasons for this are as follows: Firstly, fluctuating light can affect energetics in phytoplankton by increasing the costs for maintenance and repair of photoinhibition, thereby potentially altering the allocation of energy to other processes (e.g. calcification) (Dimier et al. 2009). Secondly, cells in the present study were exposed to solar radiation with UVR (280 to $400 \mathrm{~nm}$ ), which has been shown to enhance PIC production (Guan \& Gao 2010, $\mathrm{Xu} \&$ Gao 2015). Consequently, fluctuations of solar radiation and presence of UVR may act individually or interactively to affect the calcification of coccolithophores. Therefore, the similar responses of calcification to OA in this study and previous studies (e.g. Rokitta \& Rost 2012) might be the result of a trade-off between fluctuating light and UVR. In addition, these 2 possible mechanisms would also account for the different growth responses of E. huxleyi to OA treatment compared with that of diatoms, whose growth was enhanced under low light conditions but reduced under high sunlight levels (Gao et al. 2012). This conjecture should be investigated.

While higher light intensity appeared to offset OA impact on the calcification of E. huxleyi by increasing energy availability, further increasing light levels (to $>500 \mu \mathrm{mol}$ photons $\mathrm{m}^{-2} \mathrm{~s}^{-1}$ ) decreased the calcification under both ambient or elevated $\mathrm{CO}_{2}$ conditions (Fig. 5). This is consistent with previous findings that cellular PIC and PIC:POC in E. huxleyi both decreased when the light level was raised from 300 to $500 \mu \mathrm{mol}$ photons $\mathrm{m}^{-2} \mathrm{~s}^{-1}$ (Xu \& Gao 2015), and were lower when E. huxleyi was grown at $400 \mu \mathrm{mol}$ photons $\mathrm{m}^{-2} \mathrm{~s}^{-1}$ (Feng et al. 2008), compared to lower light levels. Since the saturating light level for photosynthesis is much higher than that for calcification in E. huxleyi (Balch et al. 1992, Bleijswijk et al. 1994), in our experiments, calcification could have been photoinhibited at relatively high light levels while photosynthesis remained unaffected, leading to markedly decreased cellular PIC quotas and PIC:POC ratios at the high light levels.

Our data showed that the calcifying and noncalcifying E. huxleyi strains responded differentially to increasing light levels under OA treatment. As discussed above, calcification should account for this discrepancy. On the other hand, these 2 strains were 
isolated from different regions, therefore their temperature reaction norms should be different (Zhang et al. 2014). Although we grew these 2 species at the same temperature level for the purpose of comparison, our results can hardly reflect their responses to OA in their natural habitat (Sett et al. 2014).

Since both $p \mathrm{CO}_{2}$ (IPCC 2013) and integrated light density in the UML (Sarmiento et al. 2004) are projected to continue to rise in the future ocean, our findings imply that POC production of coccolithophores (both calcifying and non-calcifying) will increase. Our work also showed that, while calcification and ratio of calcification to photosynthesis in $E$. huxleyi may decrease with progressive OA at deeper layers under reduced levels of solar radiation, they might not be affected in the UML, as a result of the shoaling of the UMLwith ocean warming.

Our study showed that OA and solar radiation can individually and interactively affect the physiology of coccolithophores. However, nutrient availability, ocean warming and deoxygenation (Doney et al. 2012, Gattuso et al. 2015) are also likely to alter effects of OA, so how these factors will interactively impact on phytoplankton under future ocean scenarios is still an open question (Riebesell \& Gattuso 2015). Biochemical composition of phytoplankton (e.g. fatty acid composition, phenolic compounds) has been shown to be significantly altered under OA conditions, and these changes could transfer up to secondary producers via trophic energy and nutrient transfer (Rossoll et al. 2012, Schoo et al. 2013, Jin et al. 2015). Furthermore, decreased C:N ratios (shown in this study) can improve the nutritional value of primary producers. Therefore, further knowledge is needed to understand the consequences of OA on food webs and marine biological $\mathrm{CO}_{2}$ pumps.

Acknowledgements. This study was supported by the National Natural Science Foundation (41430967), the national key research programs (2016YFA0601400), the State Oceanic Administration (National Programme on Global Change and Air-Sea Interaction, GASI-03-01-02-04), the Joint project of the National Natural Science Foundation of China and Shandong Province (No. U1606404), and the Strategic Priority Research Program of the Chinese Academy of Sciences (No. XDA1102030204).

\section{LITERATURE CITED}

Bach LT, Riebesell U, Schulz KG (2011) Distinguishing between the effects of ocean acidification and ocean carbonation in the coccolithophore Emiliania huxleyi. Limnol Oceanogr 56:2040-2050. doi:10.4319/lo.2011.56. 6.2040

Balch WM, Holligan PM, Kilpatrick KA (1992) Calcification, photosynthesis and growth of the bloom-forming cocco- lithophore, Emiliania huxleyi. Cont Shelf Res 12: 1353-1374

Bleijswijk JD, Kempers RS, Veldhuis MJ, Westbroek P (1994) Cell and growth characteristics of type A and B of Emiliania huxleyi (Prymnesiophyceae) as determined by flow cytometry and chemical analyses. J Phycol 30: 230-241

Boelen P, van de Poll WH, van der Strate HJ, Neven IA, Beardall J, Buma AGJ (2011) Neither elevated nor reduced $\mathrm{CO}_{2}$ affects the photophysiological performance of the marine Antarctic diatom Chaetoceros brevis. J Exp Mar Biol Ecol 406:38-45

Braarud T, Gaarder KR, Markali J, Nordli E (1952) Coccolithophorids studied in the electron microscope. Observations on Coccolithus huxleyi and Syracosphaera carterae. Nytt Mag Bot 1:129-134

Dimier C, Brunet C, Geider R, Raven J (2009) Growth and photoregulation dynamics of the picoeukaryote Pelagomonas calceolata in fluctuating light. Limnol Oceanogr 54:823-836

*Doney SC, Ruckelshaus M, Duffy JE, Barry JP and others (2012) Climate change impacts on marine ecosystems. Annu Rev Mar Sci 4:11-37

FFeng Y, Warner ME, Zhang Y, Sun J, Fu FX, Rose JM, Hutchins DA (2008) Interactive effects of increased $p \mathrm{CO}_{2}$, temperature and irradiance on the marine coccolithophore Emiliania huxleyi (Prymnesiophyceae). Eur J Phycol 43:87-98

*Fiorini S, Middelburg JJ, Gattuso JP (2011) Effects of elevated $\mathrm{CO}_{2}$ partial pressure and temperature on the coccolithophore Syracosphaera pulchra. Aquat Microb Ecol 64:221-232

*Gao K, Ruan Z, Villafañe VE, Gattuso JP, Helbling EW (2009) Ocean acidification exacerbates the effect of UV radiation on the calcifying phytoplankter Emiliania huxleyi. Limnol Oceanogr 54:1855-1862

Gao KS, Xu JT, Gao G, Li YH and others (2012) Rising $\mathrm{CO}_{2}$ and increased light exposure synergistically reduce marine primary productivity. Nat Clim Change 2:519-523

*Gattuso JP, Magnan A, Bille R, Cheung W and others (2015) Contrasting futures for ocean and society from different anthropogenic $\mathrm{CO}_{2}$ emissions scenarios. Science 349: aac4722

Guan W, Gao K (2010) Impacts of UV radiation on photosynthesis and growth of the coccolithophore Emiliania huxleyi (Haptophyceae). Environ Exp Bot 67:502-508

Koppe CJ, Holtz LM, Trimborn S, Rost B (2015) Ocean acidification decreases the light use efficiency in an Antarctic diatom under dynamic but not constant light. New Phytol 207:159-171

*Hutchins DA (2011) Oceanography: forecasting the rain ratio. Nature 476:41-42

* Iglesias-Rodriguez MD, Halloran PR, Rickaby RE, Hall IR and others (2008) Phytoplankton calcification in a high$\mathrm{CO}_{2}$ world. Science 320:336-340

IPCC (Intergovernmental Panel on Climate Change) (2013) Summary for Policymakers. In: Stocker TF, Qin D, Plattner GK, Tignor $\mathrm{M}$ and others (eds) Climate change 2013: the physical science basis. Contribution of Working Group I to the Fifth Assessment Report of the Intergovernmental Panel on Climate Change. Cambridge University Press, Cambridge, p 3-33

* Irie T, Bessho K, Findlay HS, Calosi P (2010) Increasing costs due to ocean acidification drives phytoplankton to be more heavily calcified: optimal growth strategy of coccolithophores. PLOS ONE 5:e13436

Jin P, Gao K (2016) Reduced resilience of a globally distrib- 
uted coccolithophore to ocean acidification: confirmed up to 2000 generations. Mar Pollut Bull 103:101-108

Jin P, Gao K, Villafañe VE, Campbell DA, Helbling EW (2013) Ocean acidification alters the photosynthetic responses of a coccolithophorid to fluctuating ultraviolet and visible radiation. Plant Physiol 162:2084-2094

* Jin P, Wang T, Liu N, Dupont S and others (2015) Ocean acidification increases the accumulation of toxic phenolic compounds across trophic levels. Nat Commun 6:8714

Kropuenske LR, Mills MM, van Dijken GL, Bailey S, Robinson DH, Welschmeyer NA, Arrigoa KR (2009) Photophysiology in two major Southern Ocean phytoplankton taxa: photoprotection in Phaeocystis antarctica and Fragilariopsis cylindrus. Limnol Oceanogr 54:1176-1196

Kanger G, Nehrke G, Probert I, Ly J, Ziveri P (2009) Strainspecific responses of Emiliania huxleyi to changing seawater carbonate chemistry. Biogeosciences 6:4361-4383

LaRoche J, Rost B, Engel A (2010) Bioassays, batch culture and chemostat experimentation. In: Riebesell U, Fabry VJ, Hansson L, Gattuso JP (eds) Guide to best practices for ocean acidification research and data reporting. Publications Office of the European Union, Luxembourg, p 81-94

Li Y, Gao K, Villafañe V, Helbling E (2012) Ocean acidification mediates photosynthetic response to UV radiation and temperature increase in the diatom Phaeodactylum tricornutum. Biogeosciences 9:3931-3942

Li Y, Zhuang S, Wu Y, Ren H, Chen F, Lin X, et al. (2017) Ocean acidification modulates expression of genes and physiological performance of a marine diatom. PLOS ONE 12:e0170970

Malin G, Erst GO (1997) Algal production of dimethylsulfide and its atmospheric role. J Phycol 33:889-896

* Meyer J, Riebesell U (2015) Reviews and syntheses: responses of coccolithophores to ocean acidification: a meta-analysis. Biogeosciences 12:1671-1682

* Morel FMM, Rueter J, Anderson DM, Guillard R (1979) Aquil: a chemically definded phytoplankton cullture medium for trace metal studies. J Phycol 15:135-141

Müller M, Schulz K, Riebesell U (2010) Effects of long-term high $\mathrm{CO}_{2}$ exposure on two species of coccolithophores. Biogeosciences 7:1109-1116

Nielsen MV (1995) Photosynthetic characteristics of the coccolithophorid Emiliania huxleyi (prymnesiophyceae) exposed to elevated concentrations of dissolved inorganic carbon. J Phycol 31:715-719

Raven J (2011) Effects on marine algae of changed seawater chemistry with increasing atmospheric $\mathrm{CO}_{2}$. Biology \& Environment: Proc R Irish Academy 111B:1-17

Raven JA, Crawfurd K (2012) Environmental controls on coccolithophore calcification. Mar Ecol Prog Ser 470: 137-166

Raven JA, Beardall J, Giordano M (2014) Energy costs of carbon dioxide concentrating mechanisms in aquatic organisms. Photosynth Res 121:111-124

Riebesell U, Gattuso JP (2015) Lessons learned from ocean acidification research. Nat Clim Change 5:12-14

Riebesell U, Tortell PD (2011) Effects of ocean acidification on pelagic organisms and ecosystems. In: Gattuso JP, Hanson L (eds) Ocean acidification. Oxford University Press, Oxford, p 99-121

Riebesell U, Zondervan I, Rost B, Tortell PD, Richard EZ, Morel FMM (2000) Reduced calcification of marine plankton in response to increased atmospheric $\mathrm{CO}_{2}$. Nature 407:364-367

Rokitta SD, Rost B (2012) Effects of $\mathrm{CO}_{2}$ and their modulation by light in the life-cycle stages of the coccolithophore Emiliania huxleyi. Limnol Oceanogr 57:607-618
Rossoll D, Bermúdez R, Hauss H, Schulz KG, Riebesell U, Sommer U, Winder M (2012) Ocean acidificationinduced food quality deterioration constrains trophic transfer. PLOS ONE 7:e34737

Sarmiento J, Slater R, Barber R, Bopp L and others (2004) Response of ocean ecosystems to climate warming. Global Biogeochem Cycles 18:GB3003

* Schoo KL, Malzahn AM, Krause E, Boersma M (2013) Increased carbon dioxide availability alters phytoplankton stoichiometry and affects carbon cycling and growth of a marine planktonic herbivore. Mar Biol 160: 2145-2155

F Sett S, Bach LT, Schulz KG, Koch-Klavsen S, Lebrato M, Riebesell U (2014) Temperature modulates coccolithophorid sensitivity of growth, photosynthesis and calcification to increasing seawater $\mathrm{pCO}_{2}$. PLOS ONE 9:e88308

Shatwell T, Nicklisch A, Köhler J (2012) Temperature and photoperiod effects on phytoplankton growing under simulated mixed layer light fluctuations. Limnol Oceanogr 57:541-553

Shi D, Xu Y, Morel F (2009) Effects of the $\mathrm{pH} / p \mathrm{CO}_{2}$ control method on medium chemistry and phytoplankton growth. Biogeosciences 6:1199-1207

* Sikes CS, Wheeler A (1982) Carbonic anhydrase and carbon fixation in coccolithophorids. J Phycol 18:423-426

* Sobrino C, Ward ML, Neale PJ (2008) Acclimation to elevated carbon dioxide and ultraviolet radiation in the diatom Thalassiosira pseudonana: effects on growth, photosynthesis, and spectral sensitivity of photoinhibition. Limnol Oceanogr 53:494-505

Stojkovic S, Beardall J, Matear R (2013) $\mathrm{CO}_{2}$ concentrating mechanisms in three southern hemisphere strains of Emiliania huxleyi. J Phycol 49:670-679

* Suffrian K, Schulz KG, Gutowska MA, Riebesell U, Bleich M (2011) Cellular pH measurements in Emiliania huxleyi reveal pronounced membrane proton permeability. New Phytol 190:595-608

* Tedetti M, Sempéré R, Vasilkov A, Charrière B and others (2007) High penetration of ultraviolet radiation in the south east Pacific waters. Geophys Res Lett 34:L12610

* Tyrrell T, Taylor A (1996) A modelling study of Emiliania huxleyi in the NE Atlantic. J Mar Syst 9:83-112

*van Leeuwe M, van Sikkelerus B, Gieskes WWC, Stefels J (2005) Taxon-specific differences in photoacclimation to fluctuating irradiance in an Antarctic diatom and a green flagellate. Mar Ecol Prog Ser 288:9-19

King T, Gao K, Beardall J (2015) Response of growth and photosynthesis of Emiliania huxleyi to visible and UV irradiances under different light regimes. Photochem Photobiol 91:343-349

Xu K, Gao K (2015) Solar UV irradiances modulate effects of ocean acidification on the coccolithophorid Emiliania huxleyi. Photochem Photobiol 91:92-101

Zhang Y, Klapper R, Lohbeck KT, Bach LT, Schulz KG, Reusch TB, Riebesell U (2014) Between- and withinpopulation variations in thermal reaction norms of the coccolithophore Emiliania huxleyi. Limnol Oceanogr 59: 1570-1580

Khang Y, Bach LT, Schulz KG, Riebesell U (2015) The modulating effect of light intensity on the response of the coccolithophore Gephyrocapsa oceanica to ocean acidification. Limnol Oceanogr 60:2145-2157

Zondervan I, Rost B, Riebesell U (2002) Effect of $\mathrm{CO}_{2}$ concentration on the PIC/POC ratio in the coccolithophore Emiliania huxleyi grown under light-limiting conditions and different daylengths. J Exp Mar Biol Ecol 272:55-70

Submitted: June 14, 2016; Accepted: December 29, 2016

Proofs received from author(s): March 19, 2017 